\title{
Meningkatkan Kemampuan Kognitif Peserta Didik Kelas X IPS 2 Dalam Materi Perilaku Ekonomi Melalui Pendekatan Saintifik Di Sekolah Menengah Atas Negeri 12 Kota Jambi
}

\author{
Rayuna \\ Sekolah Menengah Atas Negeri 12 Kota Jambi, Indonesia
}

\begin{abstract}
The purpose of this study is to improve students' knowledge ability in economic subject in topic the economic behavioral role in economic activities through scientific approach for students in $X$ IPS2 class of the state of senior high school 12 Jambi city. This study employed the action class research. The data collected through observation, documentation and interview. Furthermore, the data analyzed by using triangulation data. This study run from September to December 2018. The result of study shows that the student's knowledge ability increased $54.83 \%$, from $22.58 \%$ to $77.41 \%$, followed by teacher's performance from $76.66 \%$ to $90 \%$ and students' activity from $41.85 \%$ to $90,25 \%$. The results inform that the saintific approach can use for teachers to improve student's knowledge ability by following the stage of sacientific approach principles.
\end{abstract}

Keywords: economic subjet, students' knowledge ability, scientific approach

\section{Pendahuluan}

Pada tahun pelajaran 2018/2019 semester ganjil pada kompetensi dasar 3.3 yaitu menganalisis peran perilaku ekonomi dalam kegiatan ekonomi menunjukkan hasil yang masih jauh dari nilai ketuntatasan belajar yang yang telah ditetapkan yaitu enampuluhlima (65) pada ulang harian yang dilakukan pada bulan Oktober 2018. Rendahnya hasil belajar peserta didik pada kompetensi dasar 3.3 kelas X IPS2 terlihat dari rendahnya nilai rata-rata hasil ulangan harian yaitu 37, 70. Hasil ini diperoleh dari jumlah nilai keselurahan dibagi jumlah peserta didik, dimana dari 31 orang peserta didik hanya 7 peserta yang memperoleh nilai di atas kriteria ketuntasan hasil belajar (KKM) atau dapat dikatakan hanya $22,58 \%$ peserta didik yang memiliki nilai diatas (KKM).

Berdasarkan pengamatan penulis, hal yang melatarbelakangi rendahnya hasil ulangan harian peserta didik dipengaruhi belum optimalnya proses pembelajaran yang dilaksanakan karena pembelajaran yang masih menngunakan pendekatan pembelajaran yang kurang memberikan ruang bagi peserta didik untuk mengeksplorasi lebih banyak. Oleh karena itu, penulis melakukan penelitian terkait upaya meningkatkan kemampuan kognitif peserta didik pada kompetensi dasar 3.3. dengan menggunakan pendekatan 
saintifik yaitu salah satu pendekatan yang digunakan dalam proses pembelajaran yang menggunakan langkah-langkah serta kaidah ilmiah dalam proses pembelajaran, dimana langkah-langkah ilmiah meliputi menemukan masasalh, merumuskan masalah, mengajukan hipotesis, mengumpulkan data, menganalisisi data dan menarik kesimpulan. (Musfiqon \& Nurdiansyah, 2015, p.42) Selanjutnya, pendekatan saintifik adalah upaya memberikan pemahaman kepada peserta didik untuk mengetahui, memahami, mempraktikkan apa yang sedang dipelajari dan mampu menganalisis hal-hal terkait materi yang disampaikan dalam proses atau kegiatan pembelajaran.

Tujuan penelitian ini adalah untuk meningkatkan kemampun kognitif peserta didik dalam menganalisis peran perilaku ekonomi dalam kegiatan ekonomi di kelas X IPS 2 SMA Negeri 12 Kota Jambi pada semester ganjil tahun akademik 2018/2019 melalui pendekatan saintifik.

\section{Pembelajaran dan Pengertiannya}

Pembelajaran adalah kegiatan yang berkaitan dengan perubahan perilaku individu atau perubahan potensial dan kemampuan seseorang sebagai hasil dari pengalaman atau praktek. (Asif Muhammad Sheikh, diakses tanggal 1 Januari 2019)

Sebagai seorang tenaga pendidik, pembelajaran adalah suatu proses mempengaruhi peserta didik untuk memberi pengalaman yang mengarahkan pada perkembangan keamampuan kognitif melalui kegiatan pembelajaran.

Selanjutnya pembelajaran dapat dikatakan sebagai proses interaksi yang berlangsung antara peserta didik dan pendidik terhadap berbagai sumber belajar yang ada di sekitar lingkungan belajar. Gagne dalam Warsita menyatakan bahwa pembelajaran sebagai suatu sistem yang bertujuan untuk membantu proses belajar melalui rangkaian peristiwa yang dirancang untuk mempengaruhi dan mendukung terjadinya proses belajar yang bersifat internal. (Bambang Warsita, 2008, p.266) Lebih lanjut Warsita mnyatakan bahwa ada lima prinsip dalam pembelajaran yaitu: (Bambang Warsita, 2008, p.266)

1. Prinsip bahwa pembelajaran sebagai usaha memperoleh perubahan perilaku dalam diri peserta didik;

2. Prinsip bahwa pembelajaran berhasil ditandai dengan perubahan perilaku dari segala aspek

3. Prinsip bahwa pembelajaran sebagai suatu kegiatan yang saling berkesinmabungan melalui tahapan-tahapan yang sistematis dan terarah;

4. Prinsip bahwa pembelajaran terjadi karena adanya sesuatu yang mendorong dan ingin dicapai;

5. Prinsip bahwa pembelajaran merupakan bentuk pengalaman.

Prinsip-prinsip pembelajaran sangat penting dalam mencapai tujuan pembelajaran secara optimal.

Dari uraian di atas maka dapat disimpulkan bahwa pembelajaran adalah suatu proses interaksi yang bertujuan untuk mengembangkan daya pikir dan perilaku peserta didik sehingga lebih terarah berdasarkan pengamatan dan pengalaman. 


\section{Pembelajaran Ekonomi}

Mata pelajaran ekonomi merupakan mata pelajaran yang menguraikan tentang perilaku manusia dalam memenuhi kebutuhannya. Melalui mata pelajaran ekonomi peserta didik didorong untuk memahami berbagai hal terkait kebutuhan, jenis kegiatan ekonomi, perilaku ekonomi, perbankan, investasi dan lain sebagainya. (E Mulyadi\&E Wicaksono, 2016, p.III) Dalam perekonomian terdapat banyak pelaku ekonomi yaitu individu, rumah tangga, keluarga, perusahaan milik pemerintah, perusahaan milik swasta dan bahkan ada masyarakat dari negara lain, dimana masing-masing pelaku dapat berdiri sendiri dan saling berinteraksi dengan pelaku ekonomi lainnya. (E Mulyadi\&E Wicaksono, 2016, p.69)

Interaksi para pelaku ekonomi dapat dilakukan dalam dua sektor, tiga sektor dan empat sektor. Bentuk dua sektor dapat ditunjukkan antara perusahaan dan rumah tangga, sedangkan tiga sektor yaitu antara rumah tangga keluarga, perusahaan dan pemerintah. Lebih lanjut hubungan interaksi yang lebih kompleks dalam kegiatan ekonomi disebut dengan interaksi empat sektor. (E Mulyadi\&E Wicaksono, 2016, p.75-78)

Jadi dalam disimpulkan bahwa pembelajaran ekonomi adalah mempelajari salah satu materi yang telah ditetapkan berupa peran perilaku ekonomi dalam kegiatan ekonomi disampaikan oleh penulis melalui kegiatan belajar dan mengajar memerlukan suatu pendekatan pembelajaran agar materi yang disampaikan dapat terserap dan dipahami oleh peserta didik dengan baik.

\section{Pendekatan Pembelajaran}

Pendekatan pembelajaran merupakan kumpulan metode dan cara yang digunakan oleh tenaga pendidik dalam melakukan kegiatan pembelajaran. (Musfiqon \& Nurdiansyah, 2015, p.37) Sedangkan menurut Abidin pendekatan diartikan sebagai cara pandang atau filosofis terhadap objek tertentu yang dipercayai tanpa perlu dibuktikan kebenarannya lagi. (Yunis Abidin, 2014, 109-110) Pendekatan pembelajaran merupakan konsep dasar yang mewadahi, menginspirasi, menguatkan dan melatari pemikiran tentang bagimana metode-metode pembelajaran diterapkan berdasarkan teori. (Musfiqon \& Nurdiansyah, 2015, p.50)

Sehingga pendekatan dalam pembelajaran dapat dikatakan sebagai cara yang digunakan dalam proses belajar mengajar yang dijadikan pedoman agar kegiatan pembelajaran yang dilakukan dapat terlaksana secara aktif dan menyenangkan untuk mencapai tujuan pembelajaran yang telah ditetapkan sebelumnya.

\section{Pendekatan Saintifik}

Menurut kamus bahasa Indonesia, pendekatan saintifik atau ilmiah adalah suatu usaha dalam kegiatan penelitian untuk menghasilkan sebuah hubungan. Pendekatan ilmiah adalah salah satu pendekatan dalam pembelajaran yang digunakan oleh pendidik. Pendekatan ilmiah memiliki pengertian sebagai konsep dasar yang menginspirasi atau melatar beakangi perumusan metode mengajar dengan menerapkan karakteristik ilmiah. (Musfiqon \& Nurdiansyah, 2015, p.51) 
Prinsip-prinsip utama dalam pembelajaran dengan menggunakan pendekatan ilmiah adalah: (Musfiqon \& Nurdiansyah, 2015, p.51-52)

1. Belajar peserta didik aktif, termasuk pembelajaran berbasis penelitian (inquiry-based learning), belajar kelompok (cooperative learning) dan belajar berpusat pada peserta didik;

2. Mengembangkan pendekatan keberagaman, yaitu menyadari bahwa peserta didik unik, kelompok peserta didik adalah unik termasuk keunikan dari kompetensi, materi. Instruktur, pendekatan dan metode mengajar serta konteks;

3. Merupakan teknik merumuskan pertanyaan dan menjawabnya melalui kegiatan observasi, bertanya, menyajikan, menyimpilkan dan menyimpulkan.

Pendekatan ilmiah ini merupakan proses berpikir logis berdasarkan fakta dan teori.

Sedangkan menurut Daryanto dalam Musfiqon dan Nurdiansyah, proses pembelajaran disebut menggunakan pendektan ilmiah jika memenuhi kriteria sebagai berikut: (Musfiqon \& Nurdiansyah, 2015, p.59-60)

1. Substansi atau materi berbasis fakta atau fenomena yang dapat dijelaskan dengan logika atau penalaran tertentu;

2. Proses pembelajaran harus terhindar dari sifat-sifat atau nilai-nilai non ilmiah.

Jadi, pendekatan ilmiah adalah pendekatan dalam pembelajaran yang mengutamakan dimensi pengamatann penalaran dan penemuan dengan menerapkan prinsip-prinsip ilmiah dan fokus pada peningkatan kemampuan kognigtif peserta didik untuk berpikir secara kritis dan mampu memecahkan masalah serta mengkomunikasikan ide-ide yang ditemukan dalam upaya mengembangkan karakter peserta didik.

\section{Kemampuan Kognitif}

Kemampuan kognitif menurut kamus besar Bahasa Indonesia adalah kemampuan yang dimilki oleh individu yang berkaitan dengan segala aktivitas mental (kognisi) berupa berpikir, memahami dan mengingat. Kemampuan kognitif menurut Gagne dan adalah merupakan kemampuan internal individu dalam berpikir, memecahkan masalah dan mengambil kesimpulan. (Gagne, R.M., \& Briggs.L.J, 1974, p.19) Lebih lanjut Gagne dan Briggs menyatakan bahwa salah satu contoh proses kognitif adalah proses dimana individu berupaya memperoleh penjelasan terhadap sesuatu melalui suatu pengamatan.

Menurut Piaget dalam Ginsburg dan Opper kemampuan kognitif adalah perkembangan pikiran secara alamai dari lahir hingga dewasa. (Ginsburg. P. H.,\& Opper.S, 2016, p.39) Selanjutnya Bloom mengatakan bahwa ada tiga domain yang harus terpenuhi dalam kegiatan pembelajaran yaitu domain kognitif, afektif dan psikomotor. Domain kognitif menurut bloom terdiri atas enam tingkatan yaitu: (Taxonomy Bloom. B. S, 1956)

1. Mengetahui yaitu peserta didik memiliki kemampuan untuk mengartikan, mengingat, mengulang, mengurutkan dan menyebutkan. 
2. Membandingkan yaitu kemampuan peserta didik untuk mengklasifikasi, berdiskusi, menjelaskan, mengidentifikasi, melaporkan, memilih, menstranslet, dan mereview.

3. Mengaplikasikan yaitu kemampuan peserta didik untuk mengaplikasikan, memilih, mendemonstrasikan, menggunakam, mengoperasikan dan memecahkan.

4. Menganalisis yaitu kemampuan peserta didik untuk menganalisis, membandingkan, mengkritisi, menguji, bertanya, membedakan dan melakukan eksperimen.

5. Mensistesis yaitu kemampuan peserta didik untuk mengembangkan, mendesain dan mengkronstruki.

6. Mengevaluasi adalah kemampuan peserta didik untuk berpendapat, memilih dan membandingkan untuk kemudian membuat keputusan atau inti dari materi yang diberikan.

Sehingga kemampuan kognitif dapat diartikan sebagai kemampuan individu untuk berpikir secara kritis melalui tahapan-tahapan yang sederhana hingga ketahapan yang lebih tinggi.

\section{Kriteria Ketuntasan Minimal Materi Peran Perilaku Ekonomi Dalam} Kegiatan Ekonomi

Kriteria ketuntasan minimal (KKM) pada materi peran pelaku ekonomi dalam kegiatan ekonomi yaitu pada kompetensi dasar 3.3 telah ditetapkan oleh penulis yaitu enampuluh lima. Sesuai dengan Silabus dan Rencana Pembelajaran yang telah dirancanga maka pembelajaran pada materi ini lebih menekankan aspek kognitif karena kompetensi dasar yang diharapkan adalah kemampuan analisis peserta didik dalam materi peran pelaku ekonomi dalam kegiatan ekonomi.

Berdasarkan hasil ulangan harian siswa kelas X IPS2 SMA Negeri 12 Kota Jambi pada tahun akademik 2018/2019 semester ganjil, rata-rata kelas masih sangat rendah yaitu 37,70 dibanding dengan kelas lain dalam materi yang sama. Selain itu hanya 7 peserta didik di kelas tersebut yang memperoleh nilai ulangan harian diatas KKM, sehingga dipersentasekan 77, $42 \%$ peserta didik masih belum mencapai KKM yang telah ditetapkan.

\section{Hipotesis}

Berdasarkan uraian di atas, maka hipotesis dalam penelitian tindakan kelas ini adalah apakah dengan pendekatan saintifik dapat meningkatkan kemampuan kognitif peserta didik dalam materi peran pelaku ekonomi terutama pada kompetensi dasar 3.3 yaitu kemampuan menganalisis di kelas X IPS2 SMA Negeri 12 Kota Jambi tahun akademik 2018/2019 semester ganjil.

Metode

Penelitian ini menggunakan penelitian tindakan kelas, karena penelitian ini bertujuan untuk meningkatkan kemampuan kognitif peserta didik. Penelitian ini memberikan kontribusi penting dalam kegiatan pembelajaran agar tujuan pembelajaran dapat tercapai secara maksimal. Kemmis dan Taggart dalam Cohen, Manion dan Morisson menyatakan bahwa penelitian tindakan kelas adalah suatu bentuk penyelidikan reflektif diri yang bersifat 
kolaboratif yang dilakukan oleh semua yang terlibat dalam situasi sosial agar meningkatkan rasionalitas dan keadilan sosial itu sendiri atau praktek pendidikan, serta memahami tentang praktek dan keadaan dimana praktek itu dilakukan. (Cohen. L., Manion. L., \& Morrison. K, 2000, p.277) Sehingga dapat dikatakan bahwa penelitian tindakan kelas adalah sebuah pendekatan penelitian untuk meningkatkan pendidikan melalui perubahannya dan belajar dari konsekuensi perubahan tersebut. (Cohen. L., Manion. L., \& Morrison. K, 2000, p.229)

Penelitian tindakan kelas ini dilakukan di SMA Negeri 12 Kota Jambi terhadap 31 siswa kelas X IPS2 pada tahun akademik 2018/2019 semester ganjil yang dilaksanakan pada bulan September sampai Desember 2018. Siklus yang digunakan dalam penelitian ini adalah siklus penelitian tindakan kelas yang telah dikemukakan oleh Kemmis dan Taggart. Siklis dalam penelitian ini terdiri atas dua siklus dengan ketetapan indikator keberhasilan yaitu $70 \%$. Sumber data dalam penelitian ini adalah data hasil pembelajaran materi ekonomi di kelas X IPS2 untuk mendapatkan data akhir hasil pembelajaran dan pendidik sebagai fasilitator untuk meningkatkan kemampuan kognitif peserta didik.

Teknik pengumpulan data dalam penelitian ini adalah lembar pengamatan yang digunakan untuk mengumpulkan data tentang kinerja pendidik dan aktivitas siswa selama pembelajaran yang meliputi pengamatan setelah diadakan tindakan siklus pertama dan pengamatan setelah diadakan tindakan siklus kedua dan hasil belajar peserta didik. Dalam upaya menguji keabsahan data penulis menggunakan trianggulasi data yaitu pengumpulan data yang sama oleh dua atau lebih peneliti yang mengamati proses pembelajaran yang sama dalam waktu yang sama juga.

\section{Hasil}

\section{Siklus I}

\section{Pengamatan Kinerja Pendidik Siklus I}

Pengamatan kinerja pendidik dilakukan bertujuan untuk mengetahui kemampuan tenaga pendidik dalam mencapai tujuan penelitian yang telah ditetapkan dengan membuat lembar pengamatan yang memiliki tingkat skor maksimal 10, yang meliputi kemampuan pendidik dalam membuka pembelajaran (kegiatan pendahuluan), kegiatan inti, dan kegiatan penutup. Pengamatan tindakan dilakukan oleh teman sejawat lainnya berdasarkan tahapan yang telah ditetapkan dalam tindakan siklus pertama. Berdasarkan pengamatan yang dilakukan oleh rekan peneliti maka hasil yang diperoleh terhadap kinerja pendidik memperoleh hasil seperti yang tercantum pada tabel 1. 
Tabel 1.Hasil pengamatan kinerja pendidik

\begin{tabular}{|l|c|c|c|}
\hline $\begin{array}{l}\text { Kegiatan } \\
\text { Pembelajaran }\end{array}$ & $\begin{array}{l}\text { Skor yang } \\
\text { diperoleh }\end{array}$ & $\begin{array}{l}\text { Skor } \\
\text { Maksimal }\end{array}$ & $\begin{array}{l}\text { Pers } \\
\text { enta } \\
\text { se }\end{array}$ \\
\hline $\begin{array}{l}\text { Kegiatan } \\
\text { Pendahuluan }\end{array}$ & 8 & 10 & 80 \\
\hline Kegiatan Inti & 7 & 10 & 70 \\
\hline Kegiatan Akhir & 8 & 10 & 80 \\
\hline
\end{tabular}

Tabel 1 menunjukkan bahwa pendidik pada siklus I berdasarkan pengamatan teman sejawat mencapai tingkat $76.66 \%$ dalam kegiatan pembelajaran

\section{Pengamatan Aktifitas Peserta Didik Siklus I}

Pengamatan aktifitas peserta didik pada siklus pertama yang dilakukan oleh rekan sejawat dengan mengikuti tahapan-tahapan dalam tindakan yang telah ditetapkan pada siklus I. Adapun kriteria aktifitas yang dinilai diklasifikasikan menjadi lima yaitu dimulai dari kategori tidak aktif, kurang aktif, cukup, aktif, dan sangat aktif. Adapun interval keaktifan tersebut di buat dalam level sebagai berikut:

a. 0-10 tidak aktif

b. 11-20 cukup

c. 21- 30 kurang aktif

d. 31-40 aktif

e. 41-50 sangat aktif

Berdasarkan interval dan kategorisasi tersebut, maka diperoleh hasil keaktifan peserta didik pada siklus I. Tabel 2 mendeskripsikan hasil keaktifan peserta didik berdasarkan lembar pengamatan yang telah ditetapkan.

Tabel 2 Hasil keaktifan peserta didik pada siklus I

\begin{tabular}{|l|l|c|c|}
\hline $\begin{array}{l}\text { Interva } \\
1\end{array}$ & Kategori & Jumlah Siswa & Persentase \\
\hline $0-10$ & Tidak aktif & 3 & 9,68 \\
\hline $11-20$ & Kurang aktif & 5 & 16,13 \\
\hline $21-30$ & Cukup Aktif & 10 & 32,25 \\
\hline $31-40$ & Aktif & 6 & 19,35 \\
\hline $41-50$ & Sangat aktif & 7 & 22,50 \\
\hline TOTAL & 31 & 100 \\
\hline
\end{tabular}

Berdasarkan tabel 2 terlihat bahwa bahwa tingkat keaktifan peserta didik masih jauh dari rata-rata yang telah ditetapkan yaitu sebesar $41,85 \%$.

\section{Hasil Ujian Siklus I}

Hasil ujian peserta didik setelah dilakukan tindakan siklus pertama menunjukkan peningkatan sebagaimana yang tertera pada tabel 3 berikut. 
Tabel 3 Hasil Ujian Siklus Pertama siswa kelas X IPS2 SMA Negeri 12 Kota Jambi

\begin{tabular}{|c|c|c|}
\hline No & Nama Siswa & Nilai \\
\hline 1 & Metta Yulanda & 75 \\
\hline 2 & Chirsmas Ronitua & 45 \\
\hline 3 & Angger Pratama & 55 \\
\hline 4 & Disriani & 65 \\
\hline 5 & M. Sidiq Febrio & 56 \\
\hline 6 & Yogi Pratama S & 56 \\
\hline 7 & Trioyogi & 40 \\
\hline 8 & Devi Aprianti & 40 \\
\hline 9 & Riyan Hidayat & 62 \\
\hline 10 & Angelina Santa & 50 \\
\hline 11 & Mona Marsi & 85 \\
\hline 12 & Samuel Farulian & 45 \\
\hline 13 & Samuel Farulian & 50 \\
\hline 14 & Liska Oktaviani & 50 \\
\hline 15 & Dede Yuliarddi & 45 \\
\hline 16 & Azka Zoni & 65 \\
\hline 17 & Jhun Abdul Fajar & 65 \\
\hline 18 & Sania Ramadewi & 56 \\
\hline 19 & Rendi Puta Wisma & 75 \\
\hline 20 & Gilang Aditya $\mathrm{H}$ & 75 \\
\hline 21 & Shafia Zuhra & 45 \\
\hline 22 & Bayu Satria & 50 \\
\hline 23 & Fiko Hari P & 55 \\
\hline 24 & Williyana Sibarani & 75 \\
\hline 25 & Afdillah Afwan & 50 \\
\hline
\end{tabular}


Tabel 3 (Lanjutan)

\begin{tabular}{|l|l|c|}
\hline No & Nama Siswa & Nilai \\
\hline 26 & Stephani & 50 \\
\hline 27 & Lusi PutriYani & 80 \\
\hline 28 & Tio Yuda P & 75 \\
\hline 29 & Hasian S & 75 \\
\hline 30 & Andreas Fajar S & 50 \\
\hline 31 & Rahrul Rozi & 50 \\
\hline Jumlah Rata-Rata & 1.809 \\
\hline
\end{tabular}

Tabel 3 menampilkan tentang hasil nilai ujian peserta didik, dimana total jumlah nilai adalah 1.809, dan memiliki persentase sebesar 58, 35 untuk rata-rata kelas. Sementara jumlah peserta didik yang mencapai nilai KKM sebanyak 11 peserta atau setara dengan $35,48 \%$.

\section{Refleksi Tindakan Siklus I}

Setelah dilaksanakan tindakan pada siklus I maka perlu dilaksanakan refleksi untuk menentukan bagaimana tindakan yang dilakukan pada siklus I terlaksana dan untuk mengetahui sejauh mana tindakan yang diberikan dapat meningkatkan kemampuan kognitif peserta didik. Berdasarkan hasil siklus I terhadap kinerja pendidik, aktifitas peserta didik dan hasil ujian terhadap proses pembelajaran materi peran pelaku ekonomi dalam kegiatan ekonomi menunjukkan peningkatan yang signifikan dari sebelum dilakukan tindakan. Peningkatan terlihat dari hasil rata-rata pencapaian belajar peserta didik yang meningkat dari 37,70 menjadi 58,35 serta jumlah peserta didik yang mencapai tingkat KKM meningkat dari 7 peserta menjadi 11 peserta didik yang menunjukkan terjadi peningkatan sebesar 12,90\%

Berdasarkan refleksi tindakan siklus I di atas dapat disimpulkan bahwa melalui pendekatan saintifik kemamapuan kognitif peserta didik mengalami peningkatan sebesar 12, 90 persen meskipun begitu peningkatan ini belum mencapai persentase keberhasilan yang telah ditetapkan yaitu sebesar $70 \%$. Oleh karena itu perlu dilakukan tindakan pada siklus II.

\section{Siklus II}

\section{Pengamatan Kinerja Pendidik Siklus II}

Pengamatan kinerja pendidik pada siklus II dilakukan oleh teman sejawat dengan hasil yang tertera pada tabel 4 . 
Tabel 4 Hasil pengamatan kinerja pendidik

\begin{tabular}{|l|l|l|c|}
\hline $\begin{array}{l}\text { Kegiatan } \\
\text { Pembelajaran }\end{array}$ & $\begin{array}{l}\text { Skor } \\
\text { yang } \\
\text { diperoleh }\end{array}$ & $\begin{array}{l}\text { Skor } \\
\text { Maksimal }\end{array}$ & Persentase \\
\hline $\begin{array}{l}\text { Kegiatan } \\
\text { Pendahuluan }\end{array}$ & 9 & 10 & 90 \\
\hline Kegiatan Inti & 9 & 10 & 90 \\
\hline Kegiatan Akhir & 9 & 10 & 90 \\
\hline
\end{tabular}

Tabel 4 menunjukkan bahwa pendidik pada siklus II berdasarkan pengamatan teman sejawat mencapai tingkat $90 \%$ dalam kegiatan pembelajaran

\section{Pengamatan Aktifitas Peserta Didik Siklus II}

Pengamatan kinerja pendidik pada siklus II dilakukan oleh teman sejawat dengan hasil yang tertera pada tabel 5 .

\begin{tabular}{|c|c|c|}
\hline No & Nama Siswa & Nilai \\
\hline 1 & Metta Yulanda & 80 \\
\hline 2 & Chirsmas Ronitua & 60 \\
\hline 3 & Angger Pratama & 65 \\
\hline 4 & Disriani & 66 \\
\hline 5 & M. Sidiq Febrio & 66 \\
\hline 6 & Yogi Pratama S & 67 \\
\hline 7 & Trioyogi & 67 \\
\hline 8 & Devi Aprianti & 60 \\
\hline 9 & Riyan Hidayat & 68 \\
\hline 10 & Angelina Santa & 68 \\
\hline 11 & Mona Marsi & 85 \\
\hline 12 & Samuel Farulian & 65 \\
\hline 13 & Samuel Farulian & 65 \\
\hline 14 & Liska Oktaviani & 68 \\
\hline 15 & Dede Yuliarddi & 65 \\
\hline 16 & Azka Zoni & 70 \\
\hline 17 & Jhun Abdul Fajar & 70 \\
\hline 18 & Sania Ramadewi & 65 \\
\hline 19 & Rendi Puta Wisma & 80 \\
\hline 20 & Gilang Aditya H & 80 \\
\hline
\end{tabular}




\begin{tabular}{|l|l|l|}
\hline 21 & Shafia Zuhra & 60 \\
\hline 22 & Bayu Satria & 60 \\
\hline 23 & Fiko Hari P & 60 \\
\hline 24 & Williyana Sibarani & 80 \\
\hline 25 & Afdillah Afwan & 66 \\
\hline
\end{tabular}

\begin{tabular}{|l|l|c|c|}
\hline $\begin{array}{l}\text { Interva } \\
1\end{array}$ & Kategori & Jumlah Siswa & Persentase \\
\hline $0-10$ & Tidak aktif & 0 & 0 \\
\hline $11-20$ & Kurang aktif & 0 & 0 \\
\hline $21-30$ & Cukup Aktif & 4 & 12,90 \\
\hline $31-40$ & Aktif & 10 & 32,25 \\
\hline $41-50$ & Sangat aktif & 18 & 58,06 \\
\hline TOTAL & 31 & 100 \\
\hline
\end{tabular}

Berdasarkan tabel 5 terlihat bahwa bahwa tingkat keaktifan peserta didik telah mencapai standar keberhasilan telah ditetapkan sebesar 90, $25 \%$.

\section{Hasil Ujian Siklus II}

Hasil ujian peserta didik setelah dilakukan tindakan siklus pertama menunjukkan peningkatan sebagaimana yang tertera pada tabel 6 berikut.

Tabel 6 Hasil Ujian Siklus Pertama siswa kelas X IPS2 SMA Negeri 12 Kota Jambi

Tabel 6 (Lanjutan)

\begin{tabular}{|l|l|c|}
\hline No & Nama Siswa & Nilai \\
\hline 26 & Stephani & 60 \\
\hline 27 & Lusi PutriYani & 95 \\
\hline 28 & Tio Yuda P & 95 \\
\hline 29 & Hasian S & 95 \\
\hline 30 & Andreas Fajar S & 65 \\
\hline 31 & Rahrul Rozi & 60 \\
\hline Jumlah Rata-Rata & 2.176 \\
\hline
\end{tabular}

Tabel 6 menampilkan tentang hasil nilai ujian peserta didik, dimana total jumlah nilai adalah 2.176 dan memiliki persentase sebesar 70, 19 untuk rata-rata kelas. Sementara jumlah peserta didik yang mencapai nilai KKM sebanyak 24 peserta atau setara dengan 77, $41 \%$.

\section{Refleksi Tindakan Siklus II}

Setelah dilaksanakan tindakan pada siklus II maka perlu dilaksanakan refleksi untuk menentukan bagaimana tindakan yang dilakukan pada siklus II 
terlaksana dan untuk mengetahui sejauh mana tindakan yang diberikan dapat meningkatkan kemampuan kognitif peserta didik. Berdasarkan hasil siklus I terhadap kinerja pendidik, aktifitas peserta didik dan hasil ujian terhadap proses pembelajaran materi peran pelaku ekonomi dalam kegiatan ekonomi menunjukkan peningkatan yang signifikan dari sebelum dilakukan tindakan. Peningkatan terlihat dari hasil rata-rata pencapaian belajar peserta didik yang meningkat dari 58, $35 \%$ menjadi 77, $41 \%$ serta jumlah peserta didik yang mencapai tingkat KKM meningkat dari 11 peserta menjadi 33 peserta didik yang menunjukkan terjadi peningkatan sebesar $19,06 \%$.

Berdasarkan refleksi tindakan siklus II di atas dapat disimpulkan bahwa melalui pendekatan saintifik, kemampuan kognitif peserta didik mengalami peningkatan sesuai dengan indikator yang ditetapkan sebesar $70 \%$.

\section{Pembahasan}

Berdasarkan data awal yang diperoleh pada ulangan harian siswa kelas X IPS2 SMA Negeri 12 Kota Jambi pada materi peran pelaku ekonomi dalam kegiatan ekonomi pata tahun akademik 2018/2019 semeter ganjil menunjukkan hasil yang masih rendah yaitu baru tujuh peserta didik yang mencapai KKM atau dipersentasekan sebesar 22,58\% dan nilai rata-rata kelas adalah 37,70. Hasil ini menggambarkan bahwa masih banyak peserta didik yang belum memiliki kemampuan kognitif sesuai KKM pada kompetensi dasar 3.3 yaitu kemampuan menganalisis peran pelaku ekonomi dalam kegiatan ekonomi baik di dua sektor, tiga sektor maupun empat sektor. Maka, penulis mengadakan tindakan dengan menggunakan 2 siklus dengan catatan pada siklus dua kemampuan kognitif peserta didik dapat meningkat secara signifikan sesuai dengan tujuan penelitian.

Pada siklus I terlihat bahwa kinerja tenaga pendidik mencapai 76, 66\%; tingkat keaktifan peserta didik yaitu yang aktif dan sangat aktif sebesar 41,85\% dan pada hasil ujian hanya 11 siswa yang mampu mencapai KKM. Pencapaian KKM yang hanya 35, 48\% memiliki nilai berkisar antara 75 sampai 80. Hasil pada siklus I masih jauh dari hasil yang diharapkan berdasarkan indikator yang telah ditetapkan, terutama pada kemampuan menganalisis peran pelaku ekonomi pada berbagai sektor, dimana peserta didik masih kurang memahami tentang arus interaksi kegiatan pelaku ekonomi. Penulis menggunakan pendekatan saintifik dengan melakukan pengamatan pada alur/diagram yang dibuat beserta gambar-gambar dan penjelasan terkait fenomena yang ada di kehidupan nyata. Namun, menurut teman sejawat penulis masih harus meningkatkan keterampilan dalam kegiatan inti sehingga peserta didik dapat lebih aktigf dalam kegiatan pembelajaran. Maka, berdasarkan hasil siklus I, penulis melaksakanan siklus II.

Pada siklus II. Hasil yang diperoleh mengalami peningkatan yang sangat signifikan yaitu, kinerja pendidik meningkat menjadi $90 \%$, keaktifan peserta didik mengalami peningkatan lebih dari $50 \%$ menjadi $90,25 \%$ dan banyak peserta didik yang mencapai nilai KKM yaitu 24 peserta didik dengan persentase 77,41\% mencapai KKM. Jumlah siswa yang mencapai KKM lebih banyak terdapat pada rentang nilai 65 sampai 70 yaitu sebanyak 16 peserta 
didik. Sedangkan keaktifan peserta didik meningkat secara signifikan yaitu sebanyak 50\% menjadi 90, $25 \%$.

Berdasarkan uraian di atas, maka dapat dikatakan bahwa penelitian telah mencapai indikator yang telah ditetapkan sebesar $70 \%$, yaitu untuk kemampuan kognitif dan tingkat keaktifan peserta didik. Sehingga, dapat dikatakan bahwa melalui pendekatan saintifik kemampuan kognitif siswa kelas X IPS 2 SMA Negeri 12 Kota Jmabi dapat ditingkatkan.

\section{Kesimpulan}

Hasil penelitian menyimpulkan bahwa penggunaan pendekatan saintifik pada pembelajaran materi peran pelaku ekonomi dalam kegiatan ekonomi dapat meningkatkan kemampuan peserta didik dalam menganalissis peran pelaku ekonomi dalam interaksi di berbagai sektor di kelas X IPS 2 SMA Negeri 12 Kota Jambi. Pada siklus I terjadi peningkatan jumlah rata-rata peserta didik yang mencapai nilai KKM dari 7 peserta didik yang mencapai nilai KKM menjadi 11 peserta. Sehingga terjadi peningkatan pada siklus I sebesar $9,9 \%$ yaitu dari $22,58 \%$ menjadi $35,48 \%$. Selanjutnya, pada siklus II terjadi peningkatan yang sangat signifikan yaitu sebanyak 24 peserta didik mampu mencapai nilai KKM dengan kisaran nilai 65 sampai 70 sebanyak 16 peserta, 76 sampai 80 sebanyak 4 peserta dan 91 sampai 95 sebanyak 3 peserta didik. Tingkat kinerja pendidik dan keaktifan peserta didik meningkat secara signifikan mengikuti peningkatan keamampuan kognitif peserta didik berdasarkan hasil ujian.

\section{Saran}

Berdasarkan kesimpulan di atas maka disarankan bahwa pendekatan saintifik dapat diterapkan untuk meningkatkan kemampuan kognitif peserta didik dalam menganalisis peran pelaku ekonomi dalam kegiatan ekonomi. Selanjutnya pendidik dapat meningkatkan kinerja dalam tahapan inti pembelajaran dengan menciptakan suasana pembelajaran yang mendukung penerapan pendekatan saintifik dan memotivasi tingkat keaktifan peserta didik. 


\section{Daftar Rujukan}

Abidin, Yunis. 2014. Desain Sistem Pembelajaran dalam Konteks Kurikulum 2013. Bandung: Refika Aditama.

Bloom. B. S. 1956 Taxonomy of Educational Objective, Hand Book Cognitive Domain. New York: Mc Key.

Cohen. L., Manion. L., \& Morrison. K. 2000. Research methods in Education, $5^{\text {th }}$ Edition. London: RoutledgeFalmer.

Gagne, R.M., \& Briggs.L.J. 1974. Principles of Instructional Design. New York: Holt Rinehart and Winston.

Ginsburg. P. H., \& Opper.S. 2016 . Piaget's Theory of Intellectual Development, Third Edition. USA: International Psychotherapy Institute E-Book.

Mulyadi, Endang \& Wicaksono, Erick. 2016. Ekonomi SMA Kelas X.Ja karta : Yudistira.

Musfiqon \& Nurdiansyah. 2015. Pendekatan pembelajaran saintifikS idoarjo: Nizamia Learning Center.

Sheikh, Asif Muhammad, understanding educational management diakses dari www.pdfdrive.net pada taggal 1 Januari 2019.

Warsita, Bambang. 2008. Teknologi Pembelajara: Landasan dan Aplikasinya. Jakarta:Rineka Cipta. 